\title{
THE EUROPEAN CULTURAL FOUNDATION
}

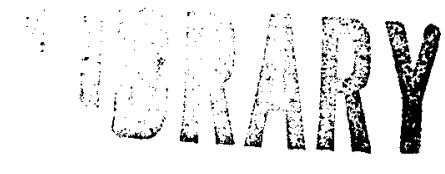

420.5 


\section{O N T EN T S}

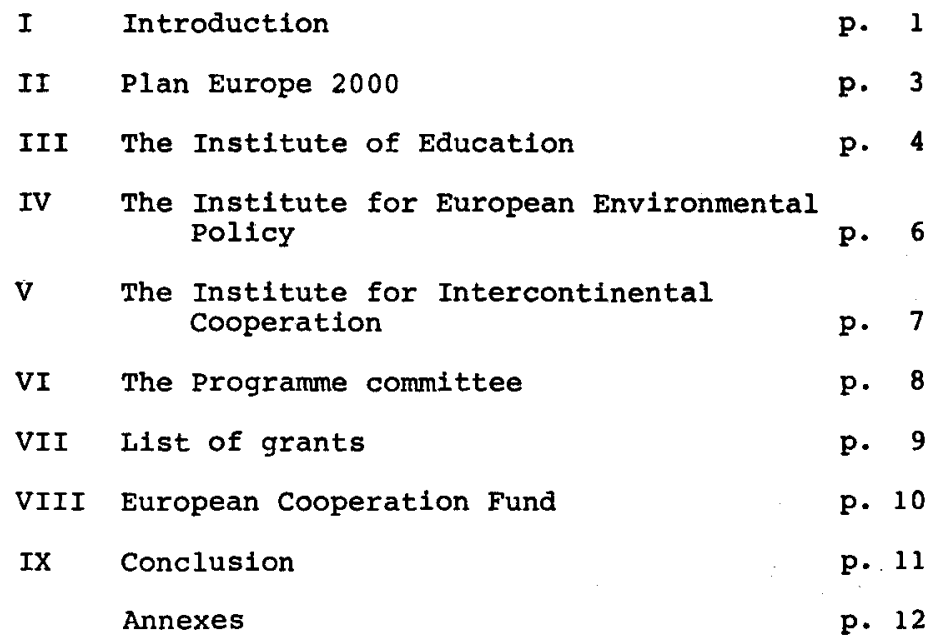

The European Cultural Foundation, having set up three institutes :

- The Institute of Education (Paris)

- The Institute for European Environmental Policy (Bonn)

- The Institute for Intercontinental Cooperation (Madrid)

founded the European Cooperation Fund in Brussels.

EUROPEAN CULTURAL FOUNDATION

Jan van Goyenkade 5

1007 AMSTERDAM

Tel: 76.02 .22 - Telex : 18701 FEC 


\section{I - INTRODUCTION}

The European Cultural Foundation was founded in Geneva in 1954 by Robert Schuman, and since 1960, has been based in Amsterdam. It is an international non-governmental organisation, which devotes most of 1 ts income to the promotion of cultural, scientific and educational activities.

The Foundation disposes of outposts in a number of countries through its network of national committees, which exist in Belgium, Denmark, Finland, France, Germany, Luxemburg, the Netherlands, Norway, Spain, Sweden, Switzerland and the United Kingdom.

Since 1973, the funds allocated to the Foundation from the Dutch football pools and National Lottery, together with contracts from outside sources to promote its scientific and cultural activities, have doubled as the figures below clearly show:-

\begin{tabular}{|c|c|c|c|c|c|c|}
\hline \multirow[t]{2}{*}{ RECEIPTS } & \multicolumn{2}{|l|}{1973} & \multicolumn{2}{|c|}{1976} & \multicolumn{2}{|c|}{1977 (1) } \\
\hline & $\frac{\text { Florins }}{2.121 .000}$ & 884.000 & $\frac{\text { F1orins }}{3.146 .000}$ & 1.311 .000 & $\frac{\text { F1orins }}{4.187 .000}$ & $\begin{array}{c}\$ \\
1.745 .000\end{array}$ \\
\hline Balance & - & - & 72.000 & 30.000 & - & - \\
\hline & 2.121 .000 & 884.000 & 3.218 .000 & .341 .000 & 4.187 .000 & .745 .000 \\
\hline
\end{tabular}

\section{EXPENDITURE}

Whereas running costs decreased from 38 to 228 of the total during this period, the amounts devoted to cultural and scientific activities have been multiplied by $4:-$

\begin{tabular}{|c|c|c|c|c|c|c|}
\hline & 1973 & & 197 & & 1977 & $(1)$ \\
\hline & Florins & $\$$ & Florins & 8 & Florins & 8 \\
\hline $\begin{array}{l}\text { Scientific } \\
\text { Activities } \\
\text { Cultural }\end{array}$ & 658.000 & 274.000 & 1.316 .000 & 548.000 & 2.487 .000 & 1.036 .000 \\
\hline $\begin{array}{l}\text { Activities } \\
\text { Running costs } \\
\text { Pensions }\end{array}$ & $\begin{array}{c}120.000 \\
802.000 \\
-\end{array}$ & $\begin{array}{r}50.000 \\
334.000 \\
-\end{array}$ & $\begin{array}{l}846.000 \\
956.000 \\
100.000\end{array}$ & $\begin{array}{r}353.000 \\
398.000 \\
42.000\end{array}$ & $\begin{array}{l}676.000 \\
924.000 \\
100.000\end{array}$ & $\begin{array}{r}281.000 \\
386.000 \\
42.000\end{array}$ \\
\hline Balance & 541.000 & 226.000 & - & - & - & - \\
\hline otal & 2.121 .000 & 884.000 & 3.218 .000 & 41.000 & 4.187 .000 & 1.745 .000 \\
\hline
\end{tabular}

(1) These figures correspond to estimates as of 30 September 1977. 
The budget for the tudies in which the Foundation is involved is, however, far grater than that shown in the accounts. The Foundation undertool several joint projects with other private, governmental or international organizations, and their financial contributions amounted to approximately half the budget for each project. Thus, in 1976, indirect contributions received by the Foundation amounted to nearly 800.000 florins ( $\$ 334.000)$.

In 1977, the Foundation received in kind the equivalent of 400.000 florins $(\$ 167.000)$ :

- the rentable value of the offices placed at the disposal of the Institute of Education by the French Government (70.000 florins. (\$ 29.000)),

- support receiveil by the Institute for European Environmental Policy from the FUST (Fonds für Umweltstudien) in the form of joint studie! (193.000 florins ( 880.000$)$ ),

- the contributiof of TNO (Central Organisation for Applied Scientific Reseirch in the Netherlands) towards the study on industrial rlations in the telecommunications sector (137.000 florins (\$58.000)).

Mr R. Georis, Secretiry General of the European Cultural Foundation, is a member of the $\mathrm{H}$ g gue $\mathrm{Club}$ which is a corporate body of. Directors of the largest 1 uropean Foundations. The European Cultural Foundation is in close contact with a number of International Organizations such as UNESCO, the EEC, the Council of Europe, etc. 
II - PLAN EUROPE 2000

From 1968 to 1975 the Foundation concentrated its efforts in the scientific field on Plan Europe 2000. This programme of research concerniny the future of European society, covers four fields, each of which formed a "Project":-

- Educating man for the 2 lst century,

- Man and Industry of tomorrow,

- Urbanization: planning human environment in Europe,

- The future of agriculture and the environment.

Professor Peter Hall of the University of Reading conducted the last phase of the Plan, integrating the results of all the studies undertaken.

Some 47 volumes in 8 languages have already set forth the results of the Plan on which more than 200 workers from 15 countries have collaborated. In order to carry the Plan to its successful conclusion, some D. Fl. 7.354.000 (\$ 3.064.000) were spent out of which D.Fl. 4.398 .000 ( $\$ 1$ 1.833.000) came from external sources, the balance being covered by the Foundation from its own funds.

The studies of Plan Europe 2000 were not just carried out for the sake of science, they were also meant to indicate ways and means of implementing the proposals made. This was done through two main publications:-

- a synthesis of the education project published in English

- entitled "Education without Frontiers" (Duckworth, London 1976),

- a general synthesis of the whole Plan, published in English with the title "Europe 2000" in December 1977, (Duckworth, London).

It is therefore a direct result of Plan Europe 2000 that the Foundation, pursuing its policy of decentralization, established three new Institutes:

- the Institute of Education set up in Paris in 1974,

- the Institute of Environment established in Bonn in 1975,

- the Institute for Intercontinental cooperation, dealing with cooperation between Europe/Latin America/Mediterranean areas, founded in Brussels/Madrid at the beginning of 1977 .

These Institutes are integral parts of the Foundation, but possess their own independent councils which decide the research programmes within budgets approved by the Foundation. The latter also ensures that the programmes conform to the aims of the Foundation, as defined by the statutes. 


\section{III - THE INSTITUTE OF EDUCATION}

The Institute is supported by the French Government, which has provided premises at the University of Paris-Dauphine, by the Commission of the European Communities through its award of research contracts, and the Council of Europe. The two latter bodies are represented on the Council of the Institute, the first by the Comissioner in charge of education and the second by the Director of Cultural, Scientific and educational affairs. The Chairman of the Institute is Professor Asa Briggs, Provost of Worcester College, Oxford (England) and it is directed by Mr L. Cerych.

The Institute meets two important needs:

- the need to coordinate on a European level, the results of national research,

- the need to complete the studies of inter-governmental bodies by independent critical analysis and assessment.

It is primarily concerned with three sets of problems:

- those connected with post compulsory education, 1.e. the last years of secondary education, profeesional training, higher education, and permanent education,

- those which call for educational measures on a European level, such as student mobility w1thin Europe, inter-university co-operation and all forms of educational exchange,

- the education dimension of major econonic and social problems shared by most European countries, for example regional development, the environment of migrant workers, which cannot be catered for on a national level.

The Institute publishes a journal three times a year entitled "Paedagogica Europaea". The first number is devoted to "an annual review of new trends in European post-secondary education". The other two each deal with a different theme and contain reports and articles from the Institute which have not been published elsewhere. In 1977 these were:

- New trends in higher education in Europe,

- A zero growth-rate in higher education?

- University drop outs in Europe.

In 1978 the budget of the Institute of Education amounts to D.F1. 1.430 .000 (g 596.000) 
Moreover, in the educational field the Foundation has been responsible for the preparatory steps towards creating an open University at Charleroi. The execution and financing of this project were also helped by three other bodies :

- on a local level: CUNIC (Centre universitaire de Charleroi) which is composed of representatives from trade-unions, employers, and municipal and regional authorities,

- on a national level: the Belgian Ministry for French Culture,

- on a European level: the Commission of the European Communities.

Financial contributions were as follows: CUNIC: 1 million Belgian francs $(\$ 28.000)$; Belgian Ministry for French Culture 450.000 Belgian francs (\$12.700); the Commission: 800.000 Belgian francs $(\$ 25.000)$ and the Foundation: 1.600 .000 Belgian francs $(\$ 45.000)$ i.e. 408 of the total.

Several associations have conferred at European level with a view to cooperation in a specific teaching field. The Foundation has created a 'centre' which enables European cooperation between about ten such groups (1); and has accorded a grant of 100.000 florins $(\$ 42.000)$. In exchange for this financial contribution, the centre, due to the Foundation, is able to assure these associations of a head office and a permanent secretariat which reduces administrative costs by economising on the material side. Amongst these groups, let us take ACEPE (Association for the promotion of community action in lifelong education in Europe). This association unites groups throughout Europe who are carrying out pilot studies analogous to those of the Open University of Charleroi. Each group has a national or local financial backing. but ACEPE gives it a European seal and enables the exchange of information and the pooling of results.

(1) SEFI (Société européenne pour la formation des ingénieurs), ACEPE (Association pour le developpement d'actions collectives d'education permanente en Europe), CESE (Comparative Education Societies in Europe)... 
IV - THE INSTITUTE FOR A EUROPEAN ENVIRONMENTAL POLICY

Founded in December 1975, the Institute for a European Environmental policy has its headquarters in Bonn, in offices made available by the Government of the Federal Republic of Germany. Its Chairman is Mr Edgar Faure, President of the French National Assembly and $1 t$ is directed by $M r ~ K$. von Moltke. It has the same status as the Institute of Education.

The Institute endeavours to propose on an international basis, and within the environmental field, alternatives to parliamentary assemblies (national parliaments, European Parliament, Parliamentary Assembly of the Council of Europe), and to international organisations, in order to prepare decisions and open discussions on environmental issues. An independent institution is better placed to critically evaluate the information available and to assess current policies, particularly by situating them in a long-term perspective.

The Institute's programme includes the following:

- how are parliamentary assemblies actually informed on environmental policy?

- list of works and research institutes dealing with environment in Europe

- regionalisation of environmental protection,

- cooperation with FUST(1). The projects of FUST, although mainly directed at the German regional and federal parliamentary assemblies, are of immediate relevance to the european concerns of the Institute which adapts them to its needs. The first activites to be adapted in this manner concern questions of trans-frontier pollution and the establishment of a multilingual glossary of environmental terminology.

The cooperation with the Council for European Environmental Law enables the Institute to submit work undertaken and proposals for legal assessment.

A study has also been started on the structures of rural society as a subject of environmental policy.

In 1978 the budget of the Institute of Environment amounts to 897,000 florins $(\$ 374.000)$.

(1) FUST (Fonds für Umweltstudien - Fund for studies on the Environment). 


\section{$V$ - THE INSTITUTE FOR INTERCONTINENTAL COOPERATION}

This third Institute commenced work in January 1977. Its headquarters are in Madrid, although certain research is also carried out in Bruges. In addition to the Foundation, two other bodies have participated in its launching:

- The College of Europe (Bruges)

- The Urquijo Bank (Madrid)

The Institute's chief aim is to weave a network of communication, information and dialogue between those dealing with the key problems of development and of relations between Europe, Latin America and the countries of the southern and eastern Mediterranean. It will subsequently deal with other regions.

The Institute should promote comparative thinking on cultural values and in order to do this it will:

- suggest and develop research projects which might serve as a basis for its action,

- organise seminars on problems of common interest and set up a grants programme,

- facilitate the exchange of information, particularly within the economic, cultural and social frameworks of the partner countries using the results obtained by the Institute.

During the first phase, two main themes will emerge from the programme:

- the organisation of an international colloquium for June 1978 to test the methodology of the Institute's programme and to define precisely the topics that should take priority,

- a comparative study of the principal topical consequences arising from the political and economic integration carried out so far commenced in October 1977 at the Collège d'Europe in Bruges.

M. F. Herrera, former President of the Inter-American Development Bank (Washington) and currently President of UNESCO's International Fund for the Promotion of Culture, has agreed to act as President of the Council of this Institute, which is directed by Mr. M. Martinez Cuadrado.

In 1978 the budget of the Institute for Intercontinental Cooperation amounts to 770.000 florins $(\$ 321.000)$. 
VI - THE PROGRAMME COMMITTEE

The Programme Committee does not limit itself to supervising the work of the Institutes, but has developed a programme of its own. The committee is particularly preoccupied with living and working conditions, which was one of the main concerns of the Industrial Project of Plan Europe 2000. One of the main projects in which it is involved is:

- a study started in 1975 in the field of labour relations enabling T.N.O. (Central Organisation for Applied Scientific Research in the Netherlands) and the London Graduate School for Business Studies, in conjunction with the committee, to start an important programme on the "Dynamics of Industrial Relations in the field of Telecommunications in the Netherlands and in Great Britain", which should be finished in 1978 .

Within the framework of international relations, the committee also proposes to study: "the inadequacy of diplomatic structures in today's world".

Towards the end of 1977, the Programme Committee set up in London, together with PEP (Political Economic Planning) and the Rowntree Trust, a centre dealing with the problems of democratic institutions.

A sum of 200.000 florins $(\$ 83.000)$ has been accorded to the centre for 1978 . 


\section{VII - GRANTS}

In 1977 the sum of 820.000 florins $(\$ 342.000)$ was set aside for grants, the beneficiaries of which are from seven countries and include six European Organizations.

As an example, the following organizations received grants in 1977:

- Bureau europeen de l'Environnement,

- Institut d'Etudes europeennes d'Amsterdam (Nuffic) Holland,

- European Community Youth Orchestra,

- Centre pour l'Education europeenne dans l'Enseignement aux Pays-Bas, (CEVNO),

- Centre pour les Etudes européennes contempraines de l'Université de Sussex, United Kingdom,

- Jeunesse et Patrimoine architectural, France,

- European Liszt Centre, Austria,

- Amnesty International,

- Association pour l'Etude des problèmes de l'Europe,

- Dutch Council of Women Organisations, Holland,

- Institut pour la connaissance des Arts, Stockholm University Sweden,

- Administrative staff College, United Kingdon.

Moreover, the Hague Academy of International Law will receive from the Foundation in 1978, a grant of 100.000 florins $(\$ 42.000)$ for the running of the summer courses.

Applications are judged in the light of the following criteria:

- The projects submitted must endeavour to increase the awareness of the European dimension of our societies.

- They should be primarily concerned either with basic values, culture, education, environment, international relations or the problems of European society in general - excluding those subjects that lie in the strictly scientific fields, or appertain to the medical/para-medical sector.

- The projects should offer every assurance of competence and efficiency. An impact on the public sector concerned would be expected.

- The projects should preferably involve the collaboration of several bodies. 


\section{VIII - EUROPEAN COOPERATION FUND}

In the Report on the European Union, Mr Tindemans proposed the creation of a European foundation to improve cooperation between private bodies (foundations, various associations, etc) and public institutions (Governments, EEC Commission, etc) in order to promote all that can lead to a better adaptation of Europe to its citizens.

The European Council approved the principle of this foundation in Brussels in December 1977 and the official creation will take place in April 1978 in Copenhagen.

The European Cultural Foundation, having taken an interest in this project, and using its experience in this field, created the"European Cooperation Fund" (1) which is to lay the way for this new foundation.

Above all the Fund will be a "clearing house" whose aim will be to determine the needs of a European society, and will try to find the means to study and satisfy these needs by approaching public and private, national and international bodies. The financing and execution of the work is carried out in the form of joint projects.

The Fund publishes "Topical Papers" some titles of which can be mentioned here: "For a European Environmental Policy" (Edgar Faure) - "European Identity and our Future" (Henri Brugmans) - "Europe, a guilty conscience and the Media" (Georges Suffert) - "Les raisons de la peripherie" (Riccardo Petrella) - "A new social action programe for Europe" (Michael Shanks) - "Europe's role in the North-South Conflict"(Bernard Lietaer). These papers exist both in English and French.

(1) The European Cooperation Fund is situated at 60 rue de la Concorde, 1050 Brussels.

Its Statuts were approved by Royal Decree dated 12 January 1977 


\section{CONCLUSION}

Given the political situation in Europe today and the near standstill in its unification process, an organization such as the European Cultural Foundation, has a worthwhile role to play, and can be an effective bridge between private and public sectors.

AMSTERDAM, January 1978 



\section{A N N E X E S}

I Organigramme

INSTITUTE OF EDUCATION

II Council of the Institute

II Publications of the Institute

INSTITUTE FOR EUROPEAN ENVIRONMENTAL POLICY

IV Council of the Institute

V Publications of the Institute

INST ITUTE FOR INTERCONTINENTAL COOPERATION

VI Council of the Institute

EUROPEAN COOPERATION FUND

VII Council of the Fund 


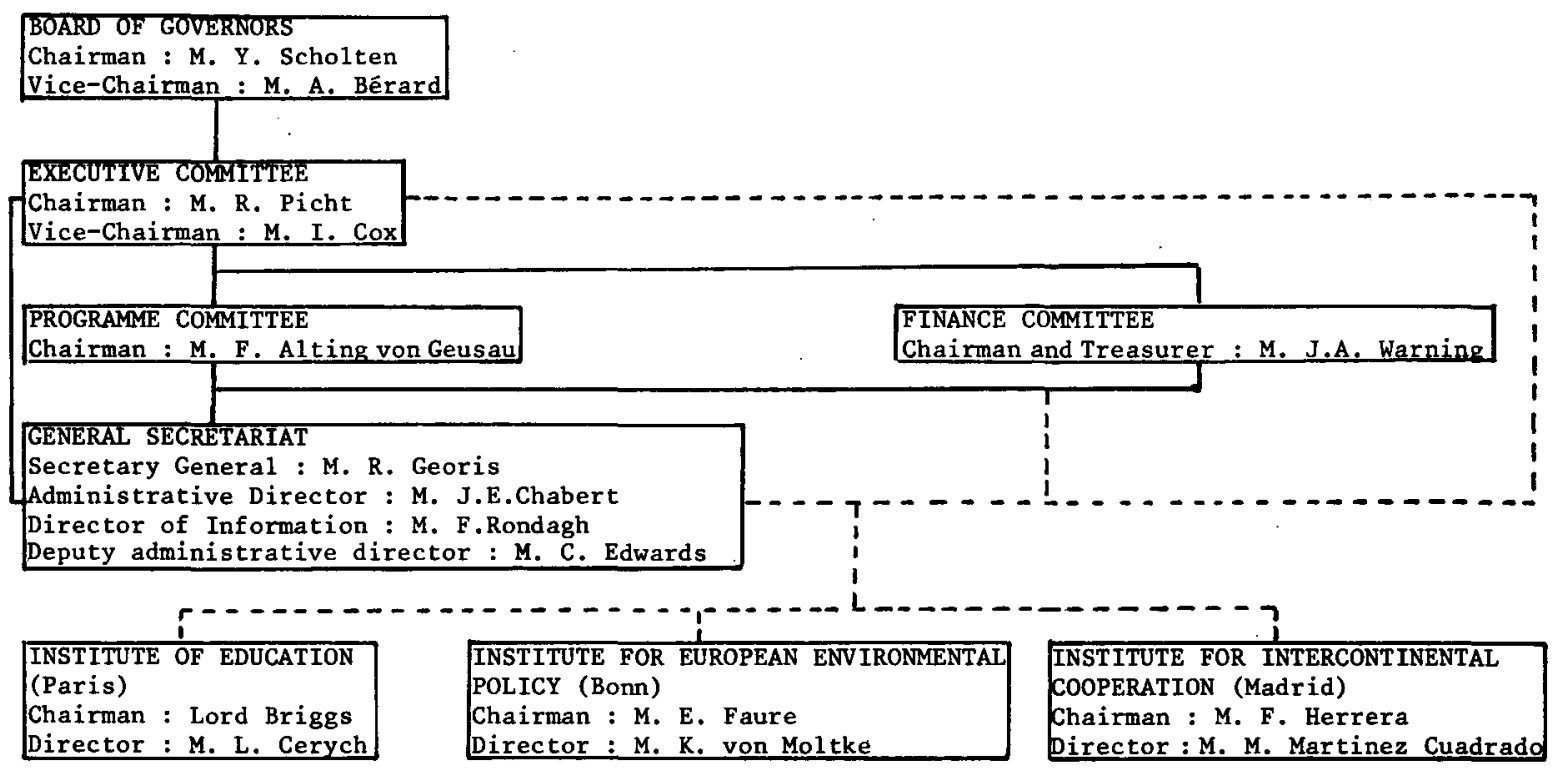


COUNCIL OF THE INSTITUTE OF EDUCATION

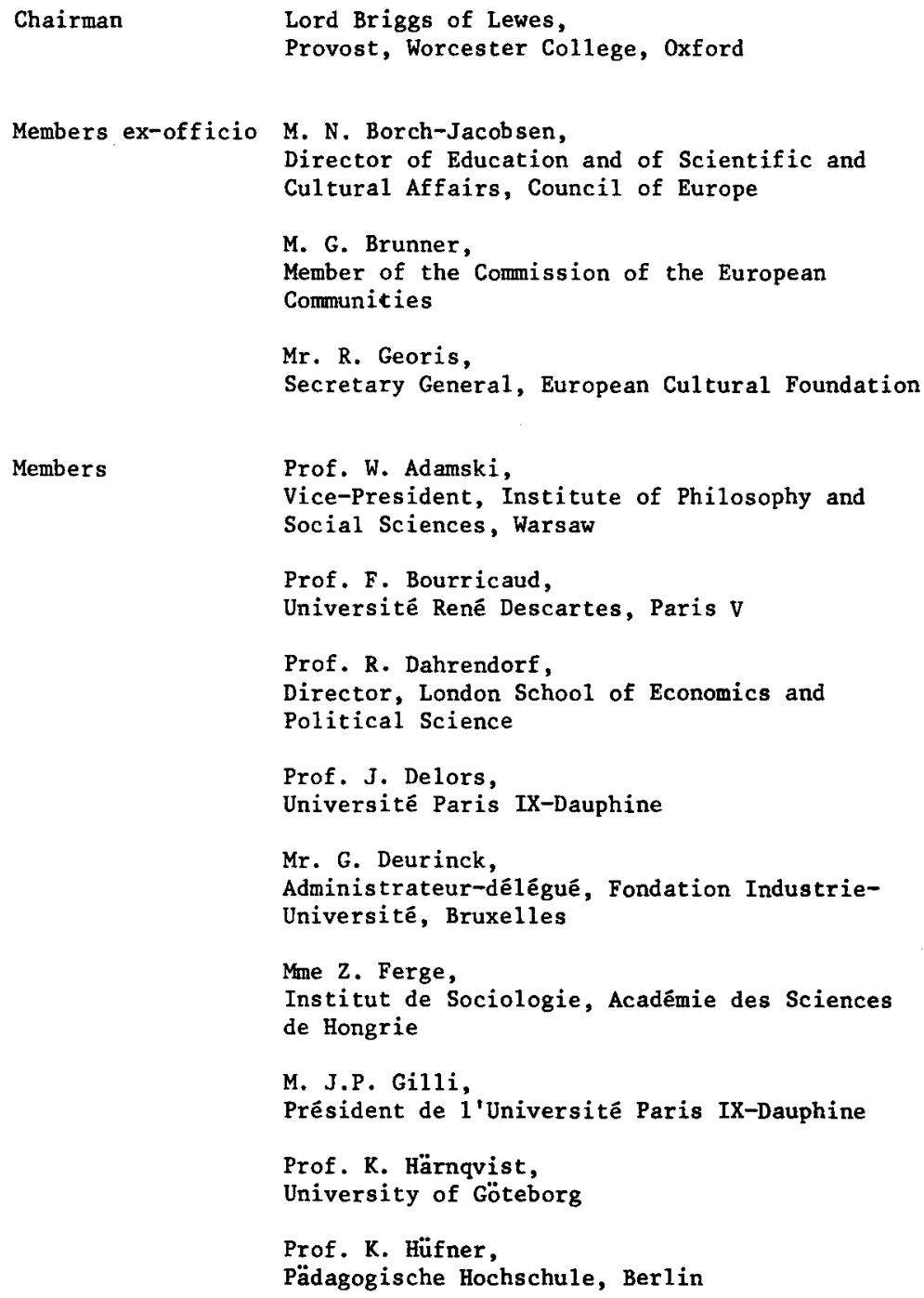


Members
Prof. H. Janne,

Président, Collège scientifique, Institut de Sociologie, Université libre de Bruxelles

Prof. D. Ka11en, Institute of Pedagogy of the University of Ams terdam

Prof. G. Martinotti, University of Turin

M. L. Cerych 


\section{PUBLICATIONS OF THE INSTITUTE OF EDUCATION}

Access and Structure of Post-Secondary Education (L. Cerych)- (out of print)

Bildungsreform und Integrationspolitik (B. Sellin)

Between School and Work (edited by L. Cerych)

Recent Student Flows in Higher Education (I. Hecquet, C. Verniers and L. Cerych)

The Intra-European Mobility of Undergraduate Students (J.C. Masclet)

Education without Frontiers (edited by G. Fragnière)

Patterns of Equality (G. Neave)

La mobilité intra-européenne des étudiants des premier et deuxième cycles (J.C. Masclet)

L'Education créatrice (rêdigé par G. Fragnière)

La Formation des enseignants demain (G. de Landsheere)

Lernen für ein neues Jahrhundert (rêdigê par G. Fragnière)

Educational leave for employees (K. von Moltke et N. Schneevoigt)

La Réforme universitaire en France et ses déboires (F. Bourricaud)

Equality, Ideology and educational policy : an essay in the history of ideas (G. Neave)

Les flux récents des étudiants de l'enseignement supérieur (I. Hecquet, C. Verniers et L. Cerych)

Education and Employment : the problems of early school-leavers (0. Magnussen) 
Annex IV

COUNCIL OF THE INSTITUTE FOR EUROPEAN ENVIRONMENTAL POLICY

Chairman

M. E. Faure,

Président de 1 'Assemblée nationale du

Parlement français

Members

M. K. Czernetz,

Chairman of the Parliamentary Assembly of the Council of Europe

M. G. Spénale,

Chairman of the European Parliament

M. W. Burhenne,

Interparlamentarische Arbeitsgemeinschaft

Bundeshaus, Bonn

Dr. H. Dichgans,

Former Managing Director, Bundesverband der

Deutschen Industrie, Köln

M. R. Georis,

Secretary General,European Cultural Foundation

M. R. Louet,

Directeur général, Conseil économique et social de la CEE, Bruxelles

Prof. E. Markelin,

Universität Stuttgart

Prof. Dr. A.A. van Trier,

Chairman, Raad van Advies voor het Wetenschapsbeleid, The Hague

Director

Dr. R. von Moltke 


\section{English}

Competence of the European Communities for Environmental Policy; Proposal for an Amendment of the Treaty of Rome (E. Grabitz \& C. Sasse)

Convention on Compensation for Transfontier Environmental Injuries; Draft with explanatory notes (A. Rest)

Environmental Law of the European Communities

International Environmental Law, Multilateral Treaties

International Environmental Programmes III

International Environmental Programes IV

International Environmental Programmes V

International Environmental Programmes, Index of Topics

Revising National Accounts (H. Jürgensen)

Special Depreciation Allowances or Subsidies? Reflections on Governmental Assistance with respect to Env Honmental Protection

Terminology of the Enviroment (compiled at the secretariat general of the European Parliament by the Terminology Office of the Directorate for Translation and Terminology Services)

Competence of the European Parliament for European Policy (Prof. H. Steiger)

For a European Environmental Policy (Edgar Faure)

\section{Français}

Amortissements exceptionnels ou subventions ? Réflexions sur les aides publiques d'adaptation dans le domaine de la protection de 1 'environnement (H. Soell)

Convention sur 1 'indemnisation des domnages transfrontières causés à l'environnement; projet de texte et exposé des motifs (A. Rest)

Droit de 1 'environnement des Communautés européennes.

Droit international de 1 'environnement. Traités multilatéraux.

Les compétences des Conmunautés européennes en matière d'environnement; proposition complétant le Traité de Rome (E.Grabitz et C. Sasse)

Programmes internationaux pour 1'environnement III

Programmes internationaux pour 1'environnement IV 
Programmes internationaux pour l'environnement $V$

Programmes internationaux pour l'environnement. Répertoire des sujets traités

Revision des comptes nationaux (H. Jurgensen)

Terminologie de l'environnement

Les compétences du Parlement européen en matière d'environnement (Prof. H. Steiger)

Pour une politique européenne de 1 'environnement (Edgar Faure)

\section{Deutsch}

Abkommen über den Schadensatz bei grenzüberschreitenden Umwe1tschäden; Entwurf mit ausführlicher Begründung (A. Rest)

Die rechtliche Behandlung der industrielle Luftverunreinigung in Frankreich und in der Bundesrepublik Deutschland (Dr. G. Ig1)

Für eine Europäische Umweltpolitik (Edgar Faure)

Internationales Umweltrecht; multilaterale Verträge

Internationale Umwe1tprogramme III

Internationale Umweltprogramme IV

Internationale Umweltprogramme $\mathrm{V}$

Internationale Umweltprogramme. Ubersicht der behande1ten Themen

Ökonomische Grundprobleme der Unweltpolitik (D. Cansier)

Revision der volkswirtschaftlichen Gesamtrechnung (H. Jürgensen)

Subvention oder Sonderabschreibung ? tberlegung zur staatlichen Anpassungsförderung im Umweltschutz (H. Soel1)

Umwe1tkompetenz der Europäischen Gemeinschaften; Vorschlag zur Ergänzung des EWG-Vertrages (E. Grabitz und C. Sasse)

Umweltkompetenz des Europäischen Parlaments (Prof. H. Steiger)

Umweltplannung in Frankreich (R. Stich)

Umweltrecht der Europäischen Gemeinschaften

Umwe1 t-Terminologie

Umweltzuständigkeiten der Europäischen Gemeinschaften (Behrens) 
Italiano

Terminologia dell'Ambiente

La competenza ecologica del Parlamento Europeo (Prof. H. Steiger)

\section{Nederlands}

Milieuterminologie

Competentie inzake milieupolitiek van het Europees Parlament

\section{Dansk}

Niljoterminologien

Miljфcompetence af det Europaeike Parlment (Frof. H. Steiger) 
Annex VI

COUNCIL OF THE INSTITUTE FOR INTERCONTINENTAL COOPERATION

Chairman

M. F. Herrera,

President of the International Fund for the

Promotion of Culture, UNESCO, Paris

Members

Prof. F. Duchêne,

Director, Centre for Contemporary European

Studies, University of Sussex

Prof. E. Guardia de Enterria,

Professor of Administrative Law, University of Madrid

Prof. J. Lukaszewski,

Rector of the College of Europe, Bruges

M. R. Georis,

Secretary General, European Cultural Foundation

Observer

M. J.C. Langlois,

Directeur des Opérations du Fonds pour 1a

Promotion de la Culture, UNESCO, Paris

Director

Prof. M. Martinez Cuadrado 
Members
Prof. F. Alting von Geusau, University of Tilburg, Director John F. Kennedy Institute

M. J.E. Chabert, Administrative Director, European Cultural Foundation, Amsterdam

M. R. Georis, Secretary General, European Cultural Foundation, Ams terdam

M. J.D. Jurgensen, Ambassador, Paris

The Right Hon. G. Rippon, Member of the British Parliament, Chairman of the Conservative Group of the European Parliament

M. Y. Scholten, Lawyer, former Dutch Minister of Justice, Chairman of the European Cultural Foundation, The Hague

M. J.A. Warning, Member of the Executive Committee of the Union of Netherlands Navigation, Hilversum

M. W. Welling,

Director B. van Leer Foundation, The Hague

Jacqueline Langdon 


